\title{
Incidents in the Life of a Slave Girl, Education and Abolition
}

\section{Kabria Baumgartner University of Massachusetts, Amherst}

Some thirty years before Harriet Ann Jacobs opened the Jacobs Free School in Alexandria, Virginia in January 1864 , one of her first students was her fifty-threeyear-old uncle, Fred. The seventeen-year-old Harriet appreciated her uncle's "most earnest desire to learn to read" and promised to teach him. ${ }^{1}$ As slaves, both teacher and student risked the punishment of "thirtynine lashes on [the] bare back" as well as imprisonment for violating North Carolina's anti-literacy laws targeting African Americans. ${ }^{2}$ Nevertheless they agreed to meet three times a week in a "quiet nook" where she instructed him in secret. ${ }^{3}$ While the primary goal for him was to read the Bible, this moment in Jacobs' slave narrative Incidents in the Life of a Slave Girl revealed her early commitment to African American literacy and education as well as her rejection of the laws of American slavery. In that moment, the vocations of education and abolition took root for Harriet Jacobs. 
Throughout her life, Harriet Jacobs embraced the twin vocations of educator and abolitionist. To expose slavery as a "pit of abominations" not only helped to undermine it, but by educating African Americans she frustrated the very idea of African American inferiority upon which slavery had been built. ${ }^{4}$ Incidents is thus not only an account of the experiences she endured as an enslaved African American woman, but also, in light of her public activities as an educator and abolitionist, a text intended to enlighten white Northern women on why and how American slavery should be abolished. Considering these aims, it is no wonder that, in a letter to her friend Amy Post, Jacobs expressed feeling somewhat conflicted about writing her life story. ${ }^{5}$ Exposing in shrewd detail the institution of American slavery ostensibly meant, for Jacobs, exposing, among others things, her sexual abuse "for the world to read." 6 With the same daring approach that she used to teach her uncle Fred to read and write, she intended to educate the hearts and minds of women in the North on the issue of African American enslavement and the notion of racial equality.

Born into slavery in Edenton, North Carolina in 1813. Harriet Jacobs had no formal education and she recognized the limits of her informal education as a slave, a fugitive slave, and, later, a free African American woman. ${ }^{7}$ Like Jacobs, many enslaved African Americans yearned to gain knowledge, but most slaveholders forbade it. Instead, they attempted to reinforce a "sense of innate inferiority" among slaves so as to mold them into being obedient and submissive. ${ }^{8}$ Yet, as historian Thomas Webber argues, enslaved African Americans, for the most part, did not absorb these teachings; rather, they developed their own ways of making sense of the world. ${ }^{9}$ For instance, when Jacobs' father taught her "to feel that African Americans [are] human beings," she realized that slaveholders regarded African American humanity as "blasphemous doctrine." 10 Thus the white slaveholder's teachings collided with the teachings of her father, and 
as a result, she learned to challenge the conception of African American slaves as merely "property," and thus inferior, anything but "human." This epiphany, however, can be considered a product of her informal education, which she certainly regarded as vital to her intellectual growth.

After Jacobs escaped to the North sometime in June 1842, the antislavery lecture tour became a forum where she conversed with abolitionists who supported the abolition of slavery and the fight for racial equality. This kind of informal education arguably prepared her and other African American abolitionists to lay claim to the rights and obligations of American citizenship. Still, according to Jacobs, none of those informal educational moments could stand in the place of a formal education, which probably explains why she worked to send her children to school. Indeed, in the second paragraph of her preface, she told her readers about her hard work to support herself as well as to provide an "education for her children."11 Whether it was her son Joseph's experience with racism in the North or her daughter Louisa's illiteracy, Incidents seems to be preoccupied with the benefits of informal and formal education, especially as education became crucial in the fight for African American equality during and after the antebellum era. Hence Jacobs acknowledged, in her narrative, the importance of both approaches in the lives of African Americans.

Rarely do historians reflect upon how Incidents not only established Jacobs as an abolitionist but as an educator, nor do many examine her educational approach specifically in light of the establishment of the Jacobs Free School three years after the publication of Incidents. ${ }^{12}$ I take up these issues in this article. I contend that Jacobs dispensed her own educational philosophy throughout Incidents to counter the dehumanizing aspects of American slavery, thereby dismantling the arguments by American slaveholders that African Americans were inferior and submissive. But even more important, Jacobs 
sought to arm African Americans and their white allies with the critical tools necessary to disarm American slavery and white racism. By analyzing Incidents in this fashion, this article places Harriet Jacobs in the long tradition of African American women educators while also revealing how African Americans conceived of education on the continuum from slavery to freedom. Not only were African American women key to the development of education as an ideal in antebellum America, but also, collectively, they viewed African American education as central to the program of racial uplift and social justice. The first part of this paper offers thus a textual analysis of Incidents meant to establish certain educational tenets that I believe Harriet Jacobs developed and adopted when she opened her school. The second part focuses on African American education and antislavery activity among African American women in the North. The last section explores the development of the Jacobs Free School in Alexandria, Virginia.

\section{What Slavery Wrought:}

\section{An Examination of Incidents}

Incidents condemned cruel American slaveholders for their foul, dishonest, and corrupt teachings, which were intended to dehumanize and subjugate African Americans. Indeed, American slaveholders tried to convince enslaved African Americans that they had no humanity, no right or claim to religious education, to basic literacy or education, and no intellectual faculties at all. African Americans were, in essence, according to these teachings, inferior. Historians like George Frederickson and Heather Williams have pointed out that the ideology of African American inferiority became a rationale supporting slavery well into the early nineteenth century. ${ }^{13}$ To survive the institution, Jacobs developed tactics that allowed her to navigate the oppressive slave environment until she eventually escaped to freedom in June 1842. Before that, she spoke of the many years in bondage that gave her the ability 
"to read the characters, and question the motives" of white slaveholders. ${ }^{14}$ When her father died, she could not pay her respects because her mistress demanded that she pick flowers for a party. ${ }^{15}$ Yet Jacobs, to comfort herself, recalled her father teaching her that slaves were human beings. Hence her condemnation of slavery allowed her to exhort the North to agitate against slavery and it also offered her an opportunity to describe how African Americans often learned to resist and reject the cruelty of slavery by practicing a distinct sense of kinship and community comprised of a belief in the values of selfdefinition and self-determination.

Part of Jacobs' educating enterprise included teaching white women of the North to challenge their value assumptions, especially when considering the experiences of enslaved African American women. The ideal of womanhood that white women of the North laid claim to were such as to exclude enslaved African American women completely. As literary scholar Hazel Carby argues in Reconstructing Womanhood, the standards of white womanhood did not apply to the lived experiences of enslaved African American women. The very notion of the "beautiful" African American woman left her vulnerable to sexual abuse. Enslaved African American women were thus set apart from "respectable" womanhood. ${ }^{16}$ For Jacobs, the heinous acts of physical and sexual abuse committed by slaveholders illustrated slavery's "deeper wrong," which, interestingly, was the title for the British publication of Incidents in 1862. ${ }^{17}$ In Incidents, she appealed to white women of the North to help abolish slavery, an institution that clearly threatened and violated the enslaved African American woman. Furthermore, her need to educate the public on this matter compelled her to continue writing despite her misgivings. As such, the pen became a necessary tool for instruction.

In the South, slaveholders and their militias often tried to police slave literacy, especially after Nat Turner's 
rebellion erupted in Southampton County, Virginia in August 1831. Since many slaveholders believed that slave literacy begat slave insurrection, the only proof needed to condemn a slave was provocatively written materials. In Incidents, Harriet Jacobs recalled that white militias in her neighborhood of Edenton, North Carolina ransacked slave cabins in search of any kind of writing and even robbed, whipped, beat, and killed slaves who had been suspected of insurrection. Made up of poor, illiterate whites, these militias, according to Jacobs, failed to realize that "the power which trampled the colored people also kept themselves in poverty, ignorance, and moral degradation."18 While searching her grandmother's cabin, the militia found a few letters written by Jacobs and immediately showed them to the captain who then questioned her. Upon finding out about her literacy, the captain "swore, and raved, and tore the paper into bits." 19 This reaction coupled with the hysteria surrounding Turner's rebellion clearly demonstrated that slave literacy troubled many slaveholders. In this scene Jacobs showed that African Americans valued reading and writing, and she alerted her readers to the situation of poor whites who also fell victim to the slave power. Thus Incidents "foreground[ed] the idea of textualityor the fact and function of writing," and, in the process, subverted prevailing myths about slavery and African American inferiority. ${ }^{20}$ Jacobs gave her targeted readership-white women of the North-a new kind of education, a counternarrative, so to speak.

In her introduction to Incidents, abolitionist Lydia Maria Child offered three explanations for Jacobs' strong writing skills, one of which she attributed to Jacobs' mistress, who "was a kind, considerate friend, who taught [Jacobs] to read and spell."21 Yet the institution of slavery did not even allow Jacobs' mistress to recognize her as anything but a slave. That was, in a sense, her mistress' illiteracy. The ambivalence for Jacobs was the bitter realization that her mistress, whom she loved, 
never recognized her as a neighbor yet bestowed upon her the privilege of reading, "which rarely [fell]," according to Jacobs, "to the lot of a slave."22 Though she could not liberate her mistress, she did "bless her memory."23 Frederick Douglass described an analogous moment in Narrative of the Life of Frederick Douglass, An American Slave when his mistress, Mrs. Auld, taught him to read and write, but stopped after her husband forbade it. For Douglass, this moment represented how easily slavery could corrupt an individual's kindness; slavery, despite what its supporters claimed, was not a benevolent or paternalistic institution. Likewise Harriet Jacobs unveiled this world of oppression on her own terms, and through informed action, committed, and called upon others, to commit toward achieving "permanent liberation."24 Unlike her mistress' teachings, Jacobs' pedagogy was to empower, to increase one's feeling of power in the face of deliberate disempowerment. Moreover, she and many other literate slaves viewed reading and writing as collective endeavors, not autonomous activities. Hence Jacobs did not object to teaching her uncle Fred or reading newspapers to other slaves in the community.

Many African Americans resisted the corrupt teachings of American slavery by maintaining a sense of kinship and community through which knowledge was shared and exchanged. What facilitated this climate, political scientist Gayle Tate argues, was the "collective resistance" of the "kinship network of family." 25 In Unknown Tongues, Tate explains that the actions and strategies of African American women as political activists came directly from their African past, their experiences to maintain a family and community during slavery, and from their efforts to create a viable free African American community in urban Northern cities like Boston and New York. Even though Jacobs' political activism began at a very early age, it arguably crystallized when she taught her fifty-three-year-old uncle Fred to read and write. There she experienced an epiphany: The North 
Carolina anti-literacy law that she broke did not reflect her own misconduct but rather impugned slaveholders who withheld basic human and civil rights from African Americans in the name of property and profit. In fact, she chastised white slaveholders in her narrative, telling them that they will have "to answer to God for sealing up the Fountain of Life from souls that are thirsting for it."26 Uncle Fred wanted to quench his thirst for religious literacy and education specifically, so when he observed that the white man "larn easy" and "got all de sense," he spoke not of innate white superiority and African American inferiority per se but instead stated plainly what the unequal distribution of educational resources had wrought. ${ }^{27}$ Uncle Fred knew that legal and extralegal challenges prohibited African American literacy and education; comparatively no oppressive forces prohibited the white man from the practice of learning. In this instance, Jacobs' self-awareness coupled with the earlier teachings of her father triggered her resistance. By demonstrating the importance of literacy in the life of a slave, Jacobs critiqued the proposed method of denying an education to African Americans; for not only was slavery an intolerable institution, as Jacobs learned, it was dangerous and violent too.

Resistance, for the African American slave, also included learning to operate within the corrupt system of American slavery in order to gain some semblance of justice. In Incidents, Jacobs told the story of Luke who had endured extreme hardships as a slave, including physical abuse. When he finally reached the North, he had a chance meeting with Jacobs. He told her that he planned to flee to Canada, which for many slaves and fugitive slaves symbolized the "only real Canaan of the American bondman." 28 Furthermore, the passage of the Fugitive Slave Law of 1850 made the North unsafe territory for the fugitive slave since this federal law demanded that Northern white citizens aid in the capture of fugitive slaves or risk fines and imprisonment. To aid 
his own escape, Luke depended on the money that his white master tried to deny him but that he found a way to procure anyway. Specifically, Luke hid some money in the pocket of his dead owner's trousers so that when the master was buried, he simply asked for, and subsequently was given, said trousers. At first glance, this act of justice comes across as being an act of deceit, but, as Luke reasoned, "You see I didn't steal it; dey gub it to me."29 This moment appeared in Jacobs' narrative well after she detailed the degrading aspects of slavery; Jacobs, then, unapologetically condoned Luke's subversive act. First, she pointed to slave law that sanctioned the theft of wages from African Americans to support her stance. Second, she argued that the corrupt system of slavery did not allow for an enslaved African American to recover his stolen wages in any other way except through trickery. ${ }^{30}$ For her, Luke's actions illustrated "how the moral sense is educated by slavery." 31 Although her audience may have wanted to pass judgment on Luke, she taught them that any judgment upon him would be misplaced; rather, she attacked the institution of slavery, exposing its immorality and inequality as well as its systematic brutality of enslaved African Americans.

After reading Incidents, it becomes clear how tied Jacobs' educational tenets were to, what we might call now, social justice principles, consisting of equal parts activism, resistance, and community. While she recognized that slavery perverted the moral sense, she believed that justice could be restored to mankind, and the first step in that process was reshaping the American mind through education. ${ }^{32}$ Whether it was her teaching her uncle Fred to read and write or her rejection of the teachings of slaveholders, Jacobs believed in the power of education. In fact, her entire narrative represented just this claim. Rhetorically, Incidents took its form from the sentimental novel, but Jacobs made it her own by molding it to fit her purposes. ${ }^{33}$ She underscored the importance of community and kinship but also stressed the significance 
of self-definition and self-determination. Her belief in the power of education to bring about social change, even while a slave, was radical, which may explain, at least in part, why she supported reforming America as opposed to abandoning the nation. Although her preface clearly stated that Incidents was meant to "arouse" white women of the North, her narrative also spoke to the African American community, especially educated African Americans. ${ }^{34}$ Parts of her narrative, then, can be read like a treatise on the value and import of formal education to secure civic rights. Yet even Jacobs recognized that white racism and white supremacy were prevalent in the nonslaveholding North in the mid-nineteenth century and had to be countered there as well.

\section{African American Education in the North}

While living in the North, Harriet Jacobs attended antislavery lectures, participated in abolitionist organizations and associations, and, according to her friend, editor, and fellow abolitionist Lydia Maria Child, frequently interacted with "intelligent persons who... [gave] her opportunities for self-improvement." ${ }^{35} \mathrm{Her}$ attendance at various antislavery meetings certainly contributed to this self-improvement, but the fact that her brother John S. Jacobs was a well-known abolitionist lecturer most certainly proved valuable to her selfeducation. For instance, John $\mathrm{S}$. Jacobs spoke at a "meeting of colored citizens" in New York City protesting the passage of the Fugitive Slave Law of 1850, which Harriet Jacobs likely attended because, at that time, she worked for the Willis family in New York. ${ }^{36}$ Even though the antislavery lecture tour acted as an informal kind of education, it educated Harriet Jacobs in ways that challenged the core teachings of slavery. The antislavery circuit became central to the training of African American activists as they learned the art of rhetoric and worked to build strong communication networks. Interestingly, Frederick Douglass said that he received his own higher 
education from "Massachusetts University, Mr. [William Lloyd] Garrison, President." 37 The influence of the abolitionist movement on African Americans cannot be underestimated. Jacobs adopted an activist model for own education; her educational mode was thus public, not private. An 1837 article in the African American newspaper, Weekly Advocate, pointed to the influential power of women educators to correct misrepresentations in the public mind and "to show the world that there is virtue... talent... and intelligence among African Americans." 38 Thus, we can see that African American women like Harriet Jacobs were at the center of African American education in antebellum America.

Free African American women in the North contributed to educational initiatives in their communities and they also spoke out on political issues. Their direct involvement in the antislavery reform movement arguably expanded the meaning of abolition to include educational opportunity and the fight for racial equality. However, being an antislavery activist in the North did not necessarily imply agreement with the notion of racial equality. Indeed, many white antislavery activists who vehemently opposed the institution of slavery did not view African Americans as equals. For example, membership in female antislavery societies was often closed to African American women. To resolve entrenched racial assumptions regarding membership, some white female antislavery societies reluctantly incorporated African American women. Unfortunately, as historian Julie Roy Jeffrey notes, African American women were too often, regarded as "an addition and an afterthought, if not second-class members." 39 Yet African American women who joined antislavery societies alongside white women demanded respect, forcing white women to face their own racism. For those white women who believed in the struggle against slavery as well as the fight for racial equality, a real sense of interracial cooperation developed. ${ }^{40}$ Nevertheless, African Americans, in their 
attempt to abolish racial discrimination in public education, encountered various problems, ranging from financial hardships to a lack of resources, as they tried to establish and run independent schools. Despite the white hostility directed toward African American education, African American women like Sarah Mapps Douglass and white women like Prudence Crandall devoted themselves to teaching and, in urban areas where a large African American population existed, quite a few independent schools progressed.

Before, during, and after the establishment of independent schools in the North for African Americans, literary societies acted as de facto educational institutions. Early literary societies, particularly, in the urban North in the late 1820s, offered, for instance, lectures, seminars, literary performances, and exhibitions to educate African Americans. In her narrative, Jacobs tracked her own efforts and that of her brother, John S. Jacobs, to open an antislavery reading room and bookstore in Rochester, New York. Unlike her brother, Harriet Jacobs did not get very involved in the antislavery movement when she arrived in the North in 1842; as such, a reading room probably took on greater meaning to her because, in a pragmatic sense, it represented something she could accomplish. ${ }^{41}$ Moreover, a reading room would fulfill various educational objectives, provide ready access to antislavery materials, and perhaps even promote a literary sensibility that merged the creative with the political. In Forgotten Readers, literary critic Elizabeth McHenry argues that African American literary societies, which included reading rooms, provided "self-improvement and refuge" and stood as models of resistance. ${ }^{42}$ Moreover, literary societies offered a forum for African Americans to "voice their demands for citizenship and equal participation."43 Literacy was important to these demands as was a formal education. In 1849, Jacobs opened the reading room and bookstore directly above Frederick Douglass' office where he worked on his newspaper, North Star. 
Though antislavery friends patronized the reading room, it eventually folded because the abolitionist sentiment was not large enough in that area to "support such an establishment" over the long term. ${ }^{44}$ Nevertheless, recounting this initiative in Incidents not only surely showed her readers that African Americans had a literary sensibility, but it also showed them that, with ambition and support, they could and probably should pursue similar kinds of educational initiatives.

African American mothers in the North, and clearly some in the South, as evidenced by Jacobs, stressed the value of education to their children. Maria W. Stewart, the first American woman to speak in public on political issues, inspired African American and white women to contribute to the fight for racial equality by educating young African Americans at the elementary and secondary levels. Published in Garrison's antislavery newspaper the Liberator in October 1831, Maria Stewart's tract on the principles of morality opined that African American mothers had the duty to instill in their children "a thirst for knowledge." 45 Harriet Jacobs fought for that education for her own children; she told her readers not once, not twice, but three times that the money she earned, working in domestic service for the Willis family, was "devote[d] to the education" of her children, Louisa and Joseph. ${ }^{46}$ Since she was unable to care for her children while hiding in her grandmother's attic, and also because she feared for their safety, she decided to have her grandmother care for Joseph. She agreed to place her seven-year-old daughter, Louisa, in the care of the Hobbs family of Brooklyn, New York primarily because educational opportunities would be available to her there. When Jacobs arrived in the North and learned that Louisa had been working as a domestic servant and had not gone to school at all, she felt betrayed. The Hobbs family had kept Louisa in a "state of ignorance" by limiting her knowledge, and Jacobs believed that they deemed Louisa's illiteracy and overall lack of an education as fit 
for the "condition of a slave." ${ }^{47}$ Despite that blow, Jacobs continued her quest to educate her children by tutoring her daughter until she could "enter an intermediate school." 48 Just as Jacobs occupied her time while in hiding, she sewed while her children read their books. To be sure, she did not neglect her children's education, which certainly challenged prevailing stereotypes that circulated about African American women such as that of the Mammy, who was often depicted as taking care of the master's children first as opposed to her own, or the Jezebel, who was depicted as lascivious, promiscuous, and un-motherly. ${ }^{49}$ Jacobs crushed both of these negative stereotypes in her narrative by stressing the importance of education in the life of her children and her own life. Likewise, in her role as an educator, she even supported the notion of white women educating themselves and subsequently their children by using her own experiences as an example.

Although Joseph and Louisa had different educational experiences in the North, the common thread in their experiences was the pervasive racism in the North. At first, Joseph was well liked by his fellow apprentices and his instructor at trade school, but when they discovered his African American ancestry, the school became an inhospitable place. His fellow apprentices scorned him ostensibly because "it was offensive to their dignity to have a "nigger" among them." ${ }^{50}$ Unsure of where to turn, he left the trade school and decided to "ship for a whaling voyage." 51 Meanwhile, John S. Jacobs found a boarding school in Clinton, New York called the Young Ladies Domestic Seminary to send Louisa. Operated by Reverend Hiram H. Kellogg, this boarding school, established in 1832, was one of the few schools to accept African American women as students. The educational aims of this seminary included providing a "thorough, Christian education" to people of limited means. ${ }^{52}$ Opportunities arose for employment at the school such as domestic work for those students who could not pay the full tuition. Many 
students who graduated from this seminary got involved in missionary work, which was fitting considering Louisa's involvement in aiding freedpeople after the Civil War. Louisa only spent a year at the Young Ladies Domestic Seminary, entering in 1849, and then leaving a year later when the institution closed its doors. Jacobs recounted these moments of racial inequality in order to detail how free African Americans in the non-slaveholding North still struggled amid the prevalence and pervasiveness of white racism.

When Jacobs traveled to England with the Willis family in March 1846, she saw schools there that possessed what American schools lacked: equality and opportunity. "Schools were established among them [poor whites]," she wrote, "and benevolent societies were active in efforts to ameliorate their condition. There was no law forbidding them to learn to read and write."53 For Jacobs, England exemplified equal access to education, which ostensibly America should try to emulate. Moreover, she reminded her readers that abolishing slavery and fighting to achieve racial equality in America went handin-hand. Although African Americans had little access to public education in the antebellum North, teaching became one way for African American and white women "to express an abolitionist commitment." 54 What made Incidents therefore such a radical narrative was that Jacobs believed in educating African Americans and she called on white women to come into the public sphere as educators; they needed to be, according to her, as active as she was.

\section{Jacobs Free School}

As I have argued earlier, Harriet Jacobs reshaped her life and the lives of her children through education, which the abolitionist movement nurtured, providing spaces and interactions for formal and informal kinds of education. This knowledge was indispensable, and just as she aimed to teach white women of the North, so too 
did she commit to teaching African Americans, albeit for a slightly different purpose. Equipping African Americans with an education provided them with a set of tools that could help them as they transitioned from slavery to freedom. Given her experiences, it is no surprise that Jacobs saw education as struggle; the quest for education was tied up with this quest for self-definition and self-determination, which slaveholders tried to withhold. Considering her reform efforts, she arguably saw that the only real way to reform American society was through struggle, to which those who belonged to the African American protest tradition knew. Hence, after the publication of Incidents in 1861, Harriet Jacobs decided to put all of her energy into education, not so much through writing or moral suasion as she had done earlier, but rather through working directly with African American freedpeople. When President Abraham Lincoln announced his preliminary emancipation proclamation in September 1862, Jacobs, like many other abolitionist women, became even more committed to relief work.

African Americans played a major role during the Civil War with African American men enlisting as soldiers and African American women serving as nurses, seamstresses, or cooks. In fact, during this time, African American women began to exercise more power and control over their lives. Historian Martha S. Jones asserts that African American women made their own "independent decision in a climate that welcomed...their assertions of public standing." 55 Their involvement allowed them to assert African American freedom as well as claim a public political voice, as seen in the case of African American female relief workers and educators like Mary S. Peake, Susie King Taylor, and Charlotte Forten, to name only a few. African American writers like Frances E.W. Harper also contributed to this claim of an independent, political voice. Though appearing years after the Civil War, Harper's novel lola Leroy was directed toward those African American leaders who could re-establish and lead 
a dynamic community into the twentieth century. Harper showed her protagonist, lola Leroy, moving down to the South to help teach African Americans, which put African American educators at the forefront of the racial and social uplift of the African American community.

Establishing the Jacobs Free School was not just about knowledge-building; it meant building freedom and uniting the community. ${ }^{56}$ After collecting funds from northern philanthropists and other benevolent organizations such as the New England Freedmen's Aid Society, Harriet Jacobs brought two African American teachers with her to Alexandria, Virginia: her daughter, Louisa, and Sarah Virginia Lawton, a Massachusetts native from a prominent family. Interestingly Jacobs tried to recruit Charlotte Forten who had already arrived in the Sea Islands in South Carolina in October 1862 and taught school in a Baptist church along with two other female teachers. ${ }^{57}$ Though Forten's journal entries at times contain remarks seemingly written by a "ethnocentric observer," her comments on African American education revealed quite a bit: "I wish some of those persons at the North who say the race is hopelessly and naturally inferior, could see the readiness with which these children, so long oppressed and deprived every privilege, learn and understand." 58 Forten's firsthand account refuted notions of African American inferiority and instead captured the willingness and eagerness of African American children to learn. Jacobs and her daughter held similar feelings. In a letter to Lydia Maria Child, the Jacobses specifically mentioned the children who "accepted our invitation to go to school, and so did all the parents for them." With the opportunity to seek an education, African American children and adults welcomed the opportunity for learning because, for once, no laws forbade their literacy and knowledge.

Nevertheless when Northern middle-class white women went to the South to establish schools for freedpeople and to engage in teaching African American 
children and adults, they often imposed Northern educational standards, to which Jacobs objected..$^{60}$ In March 1864, Jacobs ran into some financial difficulty after almost all of the donations for her school had been exhausted. In what would become a teaching moment, Jacobs encouraged African Americans to fundraise in order to support the completion of the new schoolhouse. While she acknowledged that they had to "struggle along to help themselves," she saw this moment as an opportunity to instill in them the values of self-reliance and community-building, which had not been adequately taught by Northern middle-class white women. The African American community in Alexandria raised the money needed to complete the building by hosting a fair, which enlisted the help of free African American women. This particular move was a strategic one by Jacobs, not only for its intended value to teach self-reliance, but also to break the tension among free African Americans who "feared" the "great influx of degraded contrabands would drag them all down to the same level in social estimation." ${ }^{61}$ Jacobs "[broke] up this selfish, aristocratic notion," hoping instead to bring African Americans together. 62 White Northern women often overlooked these class tensions, but Jacobs, acutely aware of them because of her experiences in the South and the North, wanted to address them head-on in order to mobilize and unite the community.

Harriet Jacobs also wanted African Americans to learn the value of self-sufficiency and autonomy, two characteristics Northern white women often ignored in their teaching. One way to promote these values was on the practical level by privileging the autonomy of African American institutions. In a letter quoted in the "Report of Friends' Association for the Aid and Elevation of Freedmen," dated March 22, 1864, Jacobs referred to the ten schools for African Americans that had been built, the largest of which was built by the freedmen who had full ownership of the property. ${ }^{63}$ What she omitted in this 
letter was the fact that this building housed the Jacobs Free School. Since freedpeople had built their own school, they had the power to make their own decisions. One of the questions that arose about school was whether white teachers or African American teachers would manage it. According to Jacobs, the freedpeople discussed the issue "sensibly" and then voted "parliamentary style," to have African American teachers manage the school. ${ }^{64}$ She recounted this important democratic moment in her letter because it illustrated that formerly enslaved African Americans exercised democracy; it proved that they could and should be part of the nation as citizens because of their careful, sensible, and thoughtful decision-making. This decision by the freedpeople also pleased Jacobs for another reason: "The fact of their giving preference to colored teachers, as managers of the establishment, seemed to us to indicate that even their brief possession of freedom had begun to inspire them with respect for their race." 65 Both Harriet and Louisa Jacobs wanted African Americans to shape their own lives and not rely on white Americans who often misunderstood them. In various letters exchanged with Lydia Maria Child and other northern abolitionists, what seemed to be most urgent for the Jacobses to depict was the agency and independence of freedpeople.

While Jacobs developed the curriculum for her school, which of course included her educational aims, her daughter, Louisa Jacobs, ran the day-to-day operations of the school. When the school opened its doors in January 1864,75 scholars were enrolled but that number swelled to 225 a few months later. ${ }^{66}$ In a letter to Lydia Maria Child, Louisa and Harriet Jacobs described their students as "fun and spirited," acknowledging the fact that the dehumanizing institution of slavery had not "crushed them."67 Rather, Louisa dreamed of her students' successes, and while looking around the room at these "little boys," she "wonder[ed] whether there is not some Frederick Douglass among them, destined to do honor 
to his race in the future."68 This reflection is interesting especially considering that white Americans, both in the North and South, unabashedly speculated as to whether fundamental differences in the intellectual capacities of African Americans and whites existed. In her letters, Louisa did not engage with this notion of fundamental intellectual differences, but she did admit to differences in temperament and her own students' difficulty in "maintaining proper discipline."69 Nevertheless, she wrote, "we put heart, mind, and strength freely into the work, and only regret that we have not more physical strength."70 Unfortunately a few months later, Louisa's health began to fail; she finished the school term, but gave up classroom teaching the following year. Instead she took responsibity for the Industrial Department, taught in the Sabbath school, and assisted her mother. ${ }^{71} \mathrm{~A}$ year later in November 1865, she and her mother established another school for freedpeople, the Lincoln School, in Savannah, Georgia, thus continuing their educational objectives.

$* * *$

Jacobs established an educational framework founded on the principles of activism, community, self-determination, and self-sufficiency. She believed that these principles would open the door for African Americans to American citizenship. In fact, Incidents ends not with marriage, which usually concluded the sentimental novel, but rather with her appreciation of her family, especially her grandmother and her uncle Philip who is called a "useful citizen" in his obituary. ${ }^{72}$ These "strange words" amazed her because they seemed to contradict the teachings of slavery, but clearly the post-Civil War era held much promise for her and other African American activists. ${ }^{73}$ To publicize the abilities of freedpeople to become exemplary Americans, Harriet Jacobs arranged for a photograph to be taken of her 
school. The Freedmen's Record described Jacobs as "irradiating" from the picture as she looked over her scholars; this image directly answered those "skeptical and superficial questions often put as to the desire and capacity of the negro race for improvement."74 Arguably, for Harriet and Louisa, the very idea of a formal educational institution existing for freedpeople was as a sign of a nation, at last, changing. "I am full of hope for the future. A Power mightier than man is guiding this revolution; and though justice moves slowly, it will come at last. The American people will outlive this mean prejudice against complexion," they wrote. ${ }^{75}$ African American leaders like Frederick Douglass, Henry Highland Garnet, and James McCune Smith visited the school, as did white abolitionists like Theodore Parker. ${ }^{76}$ In his report on the school published in the National AntiSlavery Standard, abolitionist Samuel J. May praised Jacobs as an "intelligent, judicious, invaluable" friend. ${ }^{77}$ In the Liberator, William C. Nell used Harriet and Louisa as examples to strengthen his argument that freedpeople merited full citizenship. ${ }^{78}$

Part of Jacobs' motivation to educate African Americans came from her twofold aim to dismantle the argument for slavery claiming African Americans as incapable of education and to empower former African American slaves by equipping them with the necessary tools to navigate postbellum United States. The everyday activities of Jacobs, her family, and the African American community spoke to these aims. Throughout Incidents, Jacobs embodied a unique abolitionist spirit from girlhood to womanhood, from slavery to freedom. Her life's work was to make African American people visible. She charted education as a viable objective and she carved out a space for African Americans that did not deny their experience, their voice, or their humanity but instead envisioned them as citizens of the nation. Her approach to education evolved from the moment that her mistress taught her to read and write-being literate-to the 
opening of the Jacobs Free School-being an educator. Harriet Jacobs was a pioneer, not only for her activism as an abolitionist, but also, because of her educational aims, an incredible force that helped to shape post-Civil War life in America.

\section{Notes}

1 Harriet Jacobs, Incidents in the Life of a Slave Girl [1861], in The Classic Slave Narratives, ed. Henry Louis Gates Jr. (New York: New American Library, 2002), 522. All further references to this narrative will be shortened to Incidents and will be cited in notes.

2 Heather Williams, Self-Taught: African American Education in Slavery and Freedom (Chapel Hill: University of North Carolina Press, 2005), 7 and Janet D. Cornelius, When I Can Read My Title Clear: Illiteracy, Slavery, and Religion in the Antebellum South (Columbia, SC: University of South Carolina Press, 1991), 32-33.

3 Jacobs, Incidents, 523.

4 Ibid., 440.

5 In 1852, her friend, abolitionist and women's rights activist, Amy Post, encouraged her to write her life story.

6 Harriet Jacobs to Amy Post, June 21, 1857.

7 Though rare, some slaves did attend school. See, for instance, Janet D. Cornelius, When I Can Read My Title Clear: Illiteracy, Slavery, and Religion in the Antebellum South (Columbia, SC: University of South Carolina Press, 1991), 59-84.

8 Thomas L. Webber, Deep Like the Rivers: Education in the Slave Quarter Community (New York: W.W. Norton \& Company, 1978), 27.

9 Ibid., 156.

10 Jacobs, Incidents, 451. (Emphasis mine)

11 Ibid., 440.

12 Jean Fagan Yellin, Harriet Jacob's biographer, has made very valuable contributions to the study of Harriet Jacob-s life. In this article, I build on Yellin's work by making extensive use of her edited collection, The Harriet Jacobs Family Papers, and her biography on Jacobs, Harriet Jacobs: $A$ Life.

13 See, for instance, George Frederickson, The Black Image in the White Mind:

The Debate on Afro-American Character and Destiny, 1817-1914 (Hanover, NH: Wesleyan University Press, 1987) and Heather Williams, Self-Taught: African American Education in Slavery and Freedom (Chapel Hill: University of North Carolina Press, 2005). 


\section{Ethnic Studies Review Volume $\mathbf{3 2 . 2}$}

14 Jacobs, Incidents, 460.

15 Ibid.

16 Martha Jones, All Bound Up Together: The Woman Question in African American Public Culture, 1830-1900 (Chapel Hill: University of North Carolina Press, 2007), 126.

17 The full title was The Deeper Wrong: Incidents in the Life of a Slave Girl.

18 Jacobs, Incidents, 511.

19 Ibid., 513.

20 Jacqueline Goldsby, “'I Disguised My Hand': Writing Versions of the Truth in Harriet Jacobs' Incidents in the Life of a Slave Girl," in Harriet Jacobs and Incidents in the Life of a Slave Girl: New Critical Essays, ed. Deborah M. Garfield and Rafia Zafar (New York: Cambridge University Press), 19.

21 Jacobs, Incidents, 442.

22 Ibid., 449.

23 Ibid.

24 Paulo Freire, Pedagogy of the Oppressed 30th Anniversary Edition (New York: Continuum, 2000), 54.

25 Gayle Tate, Unknown Tongues: Black Women's Political Activism in the Antebellum Era, 1830- 1860 (East Lansing: Michigan State University Press, 2003), 32.

26 Jacobs, Incidents, 523. Here Jacobs hints at this notion of retributive justice, which can be found in various speeches and texts of African American abolitionists from Bishop Richard Allen to Frederick Douglass.

27 Ibid., 522.

28

Fergus Bordewich, Bound for Canaan: The Underground Railroad and the War for the soul of America (New York: Harper Collins: 2005), 113.

29 Jacobs, Incidents, 655.

30 For Jacobs, slavery necessitated trickery, which was a form of resistance, and she did not hesitate to use it as a weapon to defeat her owner.

31 Jacobs, Incidents, 655.

32 Ibid., 599.

33 For example, her narrative did not end with marriage, but freedom, which underscored her condemnation of slavery.

34 Jacobs, Incidents, 440. 


\section{Baumgartner-Incidents in the Life of a Slave Girl}

35 Ibid., 441-442.

36 Jean Fagan Yellin, ed., The Harriet Jacobs Family Papers (Chapel Hill: University of North Carolina Press, 2008), 171.

37 Frederick Douglass, Life and Times of Frederick Douglass: His Early Life as a Slave, His Escape from Bondage, and His Complete History to the Present Time, ed. Rayford W. Logan (New York: Dover Publications, 2003), vii.

38 "To the Females of Colour," The Weekly Advocate, January 7, 1837.

39 Julie Roy Jeffrey, The Great Silent Army of Abolitionism: Ordinary Women in the Antislavery Movement (Chapel Hill: North Carolina, 1998), 64.

40 Ibid., 109.

41 Jean Fagan Yellin, Harriet Jacobs: A Life (Cambridge: Basic Books, 2004), 70.

42 McHenry, Forgotten Readers: Recovering the Lost History of African American Literary Societies (Durham: Duke University Press, 2002), 17.

43 Ibid., 142.

44 Jacobs, Incidents, 650.

45 Maria Stewart, "Religion and the Pure Principles of Morality, The Sure Foundation on Which We Must Build [8 October 1831]," in Marilyn Richardson, ed., Maria Stewart: America's First Black Woman Political Writer (Bloomington: Indiana University Press, 1987), 35.

46 Jacobs, Incidents, 647.

47 Ibid., 627.

48 Ibid., 643.

49 Deborah Gray White, Arn't I A Woman? Female Slaves in the Plantation South (New York: W.W. Norton, 1985), 61.

50 Jacobs, Incidents, 646.

51 Ibid., 646.

52 Amos Delos Gridley, History of the Town of Kirkland, New York, (New York: Hurd and Houghton, 1874), 141.

53 Jacobs, Incidents, 645.

54 Jeffrey, The Great Silent Army of Abolitionism, 128.

55 Jones, All Bound Up Together, 125.

56 Yellin, The Harriet Jacobs Family Papers, 509.

57 Ibid., 398. 


\section{Ethnic Studies Review Volume 32.2}

58 Letter from Charlotte Forten to William Lloyd Garrison, 20 November 1862, in Dorothy Sterling, ed., We Are Your Sisters: Black Women in the Nineteenth Century, (New York: W.W. Norton, 1984), 280.

59 Harriet Jacobs and Louisa Matilda Jacobs to Lydia Maria Child, 26 March 1864, in Jean Fagan Yellin, ed., The Harriet Jacobs Family Papers, 559.

60 Williams, Self-Taught, 83-84.

61 Yellin, Harriet Jacobs: A Life, 178.

62 Ibid.

63 Letter from Harriet Jacobs, quoted in "Report of Friends' Association for the Aid and Elevation of Freedmen," 22 March 1864, in Jean Fagan Yellin, ed., The Harriet Jacobs Family Papers, 556. For a list of these ten schools, see Jean Fagan Yellin, ed., The Harriet Jacobs Family Papers, 557.

64 Harriet Jacobs and Louisa Matilda Jacobs to Lydia Maria Child, 26 March 1864, in Jean Fagan Yellin, ed., The Harriet Jacobs Family Papers, 559.

65 Ibid., 559.

66 Ibid.

67 Ibid., 560.

68 Ibid.

69 Letter from Louisa Matilda Jacobs, quoted in the Third Report of a Committee of the Representatives of New York Yearly Meeting of Friends Upon the Condition and Wants of the Colored Refugees, 14 May 1864, in The Harriet Jacobs Family Papers, ed. Jean Fagan Yellin, 566.

70 Harriet Jacobs and Louisa Matilda Jacobs to Lydia Maria Child, 26 March 1864, in Jean Fagan Yellin, ed., The Harriet Jacobs Family Papers, 560.

71 Yellin, Harriet Jacobs: A Life, 179.

72 Jacobs, Incidents, 664.

73 Ibid.

74 Yellin, Harriet Jacobs: A Life, 185. To view this photo, "Coloured School at Alexandria Va 1864 Taught by Harriet Jacobs \& daughter agents of New York Friends," see Jean Fagan Yellin, ed., The Harriet Jacobs Family Papers, 640.

75 Ibid., 175.

76 Ibid., 184

77 Ibid., 183.

78 Ibid., 184. 


\section{Works Cited}

Bordewich, Fergus. Bound for Canaan: The Underground Railroad and the War for the Soul of America. New York: Harper Collins: 2005.

Carby, Hazel V. Reconstructing Womanhood: The Emergence of the Afro-American Woman Novelist. New York: Oxford University Press, 1987.

Cornelius, Janet Duitsman. When I Can Read My Title Clear: Literacy, Slavery, and Religion in the Antebellum South. Columbia: University of South Carolina Press, 1991.

Douglass, Frederick. Life and Times of Frederick Douglass: His Early Life as a Slave, His Escape from Bondage, and His Complete History to the Present Time. New York: Dover Publications, 2003.

Freire, Paulo. Pedagogy of the Oppressed. 30th Anniversary Edition. New York: Continuum, 2000.

Goldsby, Jacqueline. "“I Disguised My Hand': Writing Versions of the Truth in Harriet Jacobs's Incidents in the Life of a Slave Girl." In Harriet Jacobs and Incidents in the Life of a Slave Girl: New Critical Essays, edited by Deborah M. Garfield and Rafia Zafar, 11-43. New York: Cambridge University Press, 1996.

Gridley, Amos Delos. History of the Town of Kirkland, New York. New York: Hurd and Houghton,1874.

Jacobs, Harriet A., John S. Jacobs, Louisa Matilda Jacobs, and Jean Fagan Yellin. The Harriet Jacobs Family Papers. Chapel Hill: University of North Carolina Press, 2008.

Jacobs, Harriet. Incidents in the Life of a Slave Girl. In The Classic Slave Narratives, edited by Henry Louis Gates Jr., 439-668. New York: New American Library, 2002.

Jeffrey, Julie Roy. The Great Silent Army of Abolition: Ordinary Women in the Antislavery Movement. Chapel Hill: North Carolina, 1998.

Jones, Martha. All Bound Up Together: The Woman Question in African American Public Culture, 1830-1900. Chapel Hill: University of North Carolina Press, 2007. 
McHenry, Elizabeth. Forgotten Readers: Recovering the Lost History of African American Literary Societies. Durham: Duke University Press, 2002.

Sterling, Dorothy. We Are Your Sisters: Black Women in the Nineteenth Century. 1st edition. New York: W.W. Norton, 1984.

Stewart, Maria W., and Marilyn Richardson. Maria W. Stewart: America's First Black Woman Political Writer. Bloomington: Indiana University Press, 1987.

Tate, Gayle. Unknown Tongues: Black Women's Political Activism in the Antebellum Era, 1830- 1860. East Lansing: Michigan State University Press, 2003.

Webber, Thomas L. Deep Like the Rivers: Education in the Slave Quarter Community, 1831-1865. New York: W. W. Norton, 1978.

White, Deborah Gray. Arn't I A Woman? Female Slaves in the Plantation South. New York: W.W. Norton, 1985.

Williams, Heather Andrea. Self-Taught: African American Education in Slavery and Freedom. Chapel Hill: University of North Carolina Press, 2005.

Yellin, Jean Fagan. Harriet Jacobs: A Life. Cambridge: Basic Books, 2004. 